\title{
Chapter 3 \\ Magnesium Slag Generated by Reduction Smelting Using Pidgeon Process
}

\begin{abstract}
The generation process and behavior of magnesium reduction slag via Pidgeon process are described in this chapter. Main compositions, phases, particle size distribution and harmful elements in magnesium slag were analyzed. The state and development of the techniques of treatment and effective use of magnesium slag were reviewed. The advantages and technical challenges of integrated utilization of magnesium slag were proposed.
\end{abstract}

Keywords Magnesium slag $\cdot$ Pidgeon process $\cdot$ Dicalcium silicate $\cdot$ Fluorine pollution - Dust pollution

\subsection{Composition and Phases of Magnesium Slag from Reduction Smelting}

\subsubsection{Generation of Magnesium Slag}

During magnesium metallurgy via the Pidgeon process, pellets of raw materials react in a reduction retort at high temperature and under negative pressure. Magnesium in dolomite is reduced, becomes magnesium vapor. Under vacuum, magnesium vapor reaches a water circulation-cooling section of the reduction retort and condenses into crude magnesium ingots. After the reaction is complete, the discharge end of the reduction retort is opened, and the magnesium ingot and potassium/sodium crystallizer are removed. Slag is manually or semi-mechanically discharged. The slag remains pellet shape at high temperature, and is naturally cooled and pulverized after leaving the retort. The final slag is a powder that has a gray-white appearance, and mixed with granules that are not completely pulverized. The slag is manually transported to a slag yard for further cooling. Sometimes, water is poured on the slag to accelerate cooling. However, water spray aggravates dust flying off of the magnesium slag. For magnesium metallurgy via the Pidgeon process, the discharge of the slag and an example of the current situation of a slag field in Hongguozi production area of Huiye Magnesium Co. Ltd., Ningxia is shown in Fig. 3.1.

Magnesium slag that is piled in the open air is basically in the form of fine powder after the magnesium slag decomposes naturally. The particle size of the 


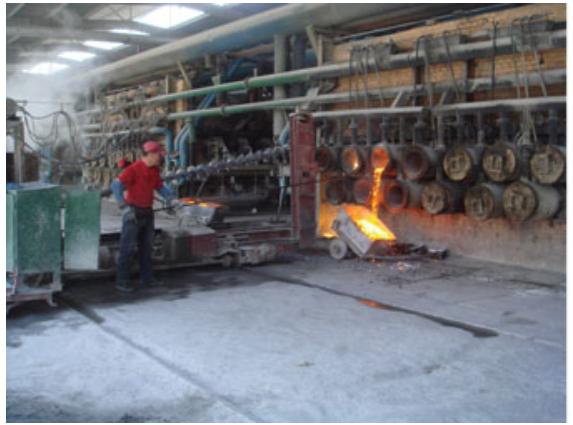

(a) Slag tapping

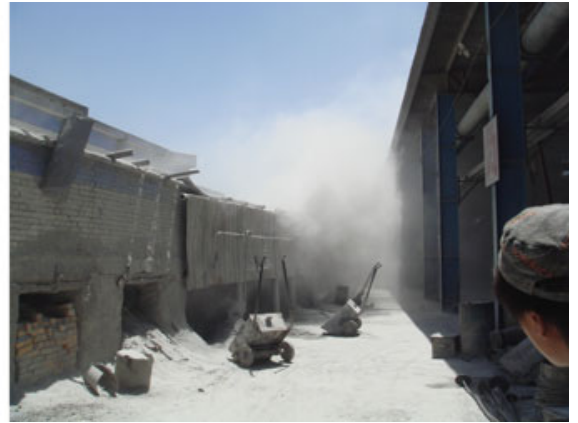

(b) Slag yard

Fig. 3.1 Huiye Magnesium Co. Ltd., Ningxia (2009)

slag is measured with a laser particle size tester (Microtrac X-100), and the particle size distribution diagram is shown in Fig. 3.2. Table 3.2 shows the corresponding composition of the slag. As seen in Fig. 3.2, the median diameter of magnesium slag that is placed for a long time is $15-16 \mu \mathrm{m}$, and the particles with a size is in the range of $1-10 \mu \mathrm{m}$ account for about $40 \%$ of the volume fraction. These tiny particles are the ones that cause harmful dust.

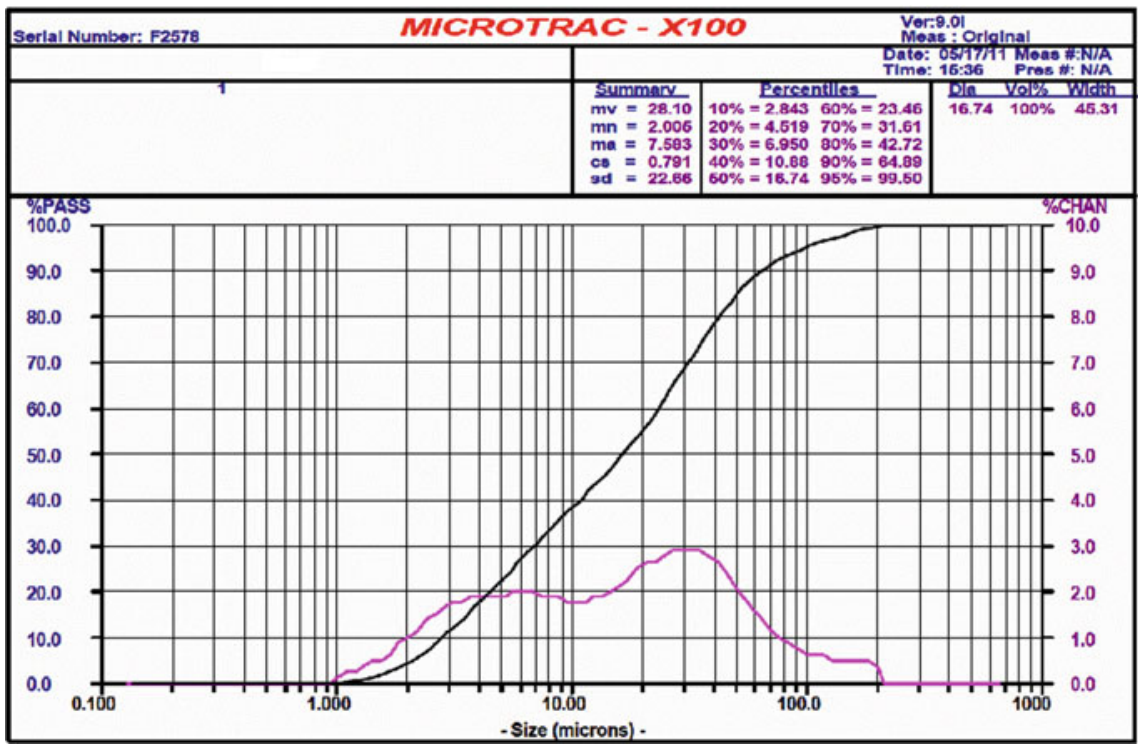

Fig. 3.2 Particle size distribution of magnesium slag of Huiye Magnesium Co. Ltd 


\subsubsection{Composition and Phases of Magnesium Slag}

The chemical components of magnesium slag include calcium silicate, silica, calcium oxide, and magnesium oxide and so on. From random sampling in the slag yard of Huiye Magnesium Co. Ltd., the detected compositions of magnesium slag are shown in Tables 3.1 and 3.2.

The composition of magnesium slag of Sun Magnesium Enterprise is shown in Tables 3.3.

The composition data of magnesium slag are different in different production batches. They are also different when different sources of raw materials are used. $\mathrm{MgO}$ content reflects if the reduction reaction is complete, and it is directly related to the product yield and heating time during reaction. Heating time is closely related to energy consumption and production costs, and so, sufficient attention must be paid to heating time. It is generally considered that $\mathrm{MgO}$ content should be controlled below 5\%. The data of $\mathrm{MgO}$ in the magnesium slag of Sun Magnesium Enterprise is obviously high, and the specific reason for this is unknown.

The phase of magnesium slag is relatively complicated, and it is related to the details of the raw materials and the production process. However, the main phase is dicalcium silicate $\left(\mathrm{Ca}_{2} \mathrm{SiO}_{4}\right.$, abbreviated as $\left.\mathrm{C}_{2} \mathrm{~S}\right)$. The X-ray diffraction patterns of the magnesium slag generated by Ningxia Huiye Magnesium Co. Ltd. and Ningxia Sun Magnesium Enterprise are shown in Figs. 3.3 and 3.4, respectively.

Table 3.1 Composition of magnesium slag of Hongguozi Section of Huiye Magnesium Co. Ltd (\%)

\begin{tabular}{l|l|l|l|l|l}
\hline Composition & Slag 1 & Slag 2 & Slag 3 & Slag 4 & Mean \\
\hline $\mathrm{SiO}_{2}$ & 29.37 & 32.6 & 31.33 & 38.6 & 32.98 \\
\hline $\mathrm{CaO}$ & 51.73 & 43.98 & 45.03 & 54.85 & 48.90 \\
\hline $\mathrm{MgO}$ & 6.41 & 4.62 & 4.67 & 3.21 & 4.73 \\
\hline $\mathrm{CaO} / \mathrm{SiO}_{2}$ & 1.76 & 1.35 & 1.44 & 1.42 & 1.48 \\
\hline
\end{tabular}

Table 3.2 Composition of magnesium slag generated by Fugu Section of Huiye MagnesiumCo. Ltd. (\%)

\begin{tabular}{l|l|l|l|l|l|l|l|l}
\hline Composition & $\mathrm{MgO}$ & $\mathrm{CaO}$ & $\mathrm{SiO}_{2}$ & $\mathrm{P}_{2} \mathrm{O}_{5}$ & $\mathrm{Fe}$ & $\mathrm{Al}$ & $\mathrm{Mn}$ & $\mathrm{Na}$ \\
\hline$\%$ & 5.12 & 42.35 & 26.78 & 0.061 & 3.85 & 0.604 & 0.061 & 0.979 \\
\hline $\mathrm{CaO} / \mathrm{SiO}_{2}$ & 1.58 & & & & & & & \\
\hline
\end{tabular}

Table 3.3 Composition of magnesium slag of Sun Magnesium Enterprise, Ningxia

\begin{tabular}{l|l|l|l|l|l|l|l|l|l}
\hline Composition & $\mathrm{CaO}$ & $\mathrm{SiO}_{2}$ & $\mathrm{Al}_{2} \mathrm{O}_{3}$ & $\mathrm{Fe}_{2} \mathrm{O}_{3}$ & $\mathrm{MgO}$ & $\mathrm{K}_{2} \mathrm{O}$ & $\mathrm{Na}_{2} \mathrm{O}$ & $\mathrm{SO}_{3}$ & $\mathrm{TiO}_{2}$ \\
\hline$\%$ & 46.13 & 26.54 & 1.53 & 5.94 & 11.82 & 0.11 & 0.09 & 0.48 & 0.01 \\
\hline $\mathrm{CaO} / \mathrm{SiO}_{2}$ & 1.74 & & & & & & & & \\
\hline
\end{tabular}




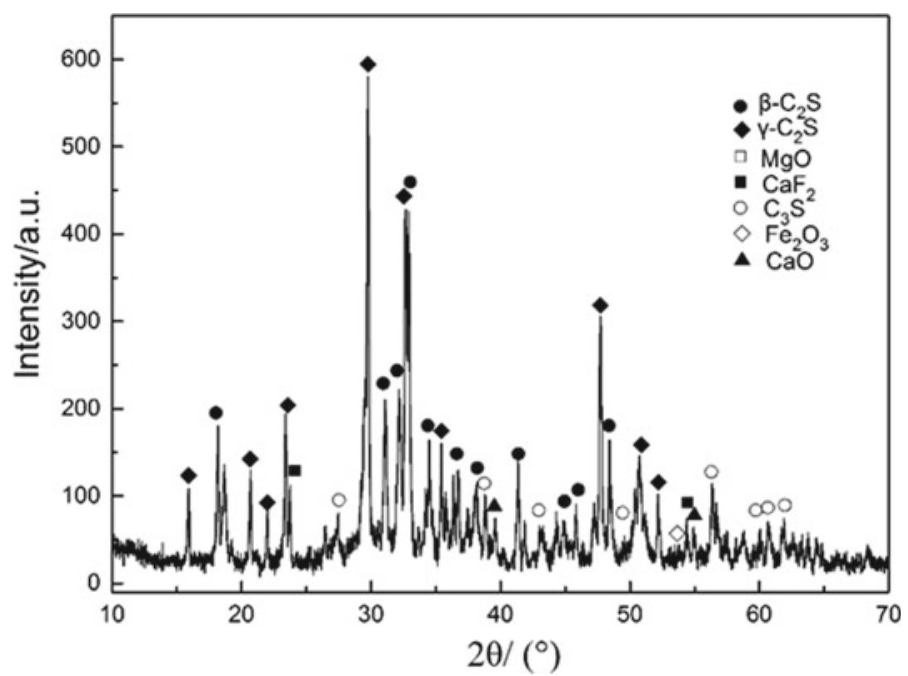

Fig. 3.3 XRD pattern of magnesium slag generated by Huiye Magnesium Co. Ltd

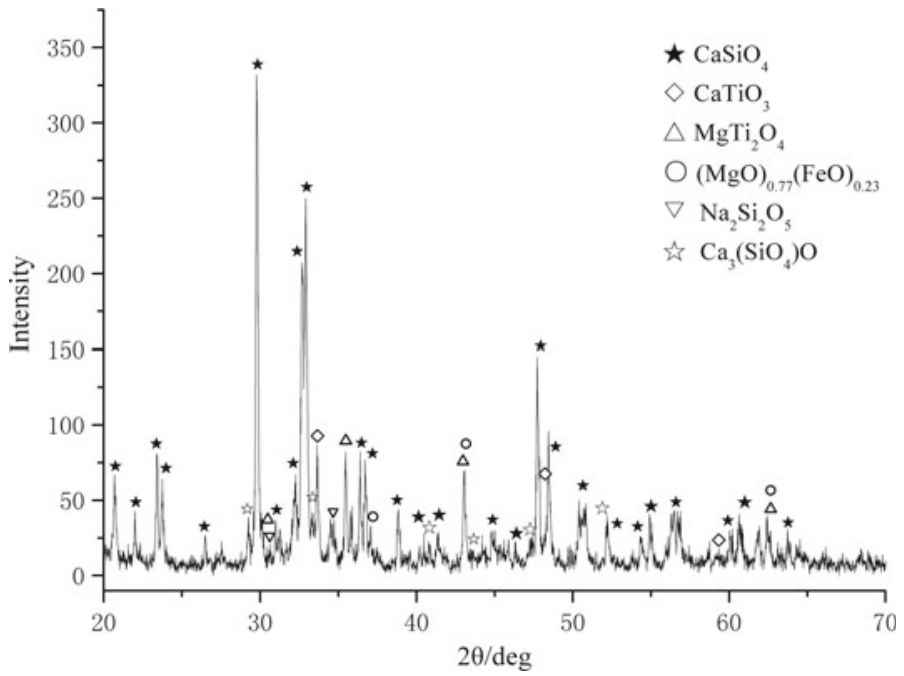

Fig. 3.4 XRD pattern of magnesium slag generated by Sun Magnesium Enterprise 


\subsection{Harmful Components in Magnesium Slag}

\subsubsection{Fluorine Pollution}

Magnesium metallurgy via the Pidgeon process requires using calcium fluoride $\left(\mathrm{CaF}_{2}\right)$ as a mineralizer, and the amount of $\mathrm{CaF}_{2}$ that is commonly added is about 2$3 \%$. Calcium fluoride does not participate in the reduction reaction; it only promotes the reaction. After the reduction reaction is complete, the calcium in the $\mathrm{CaF}_{2}$ becomes a component in the slag, and the fluorine becomes gas at high temperature and forms HF in the presence of water vapor. HF is discharged to the atmosphere through a vacuum exhaust line. Some of the calcium fluoride condenses into solid at the potassium/sodium crystallizer, in the water-cooling section of a reduction retort and enters into slag. Based on the data provided by the China Magnesium Industry Association, the pollutant emissions that are generated via magnesium metallurgy using the Pidgeon process are estimated [1]. In addition to the coal-combusting pollution, the main pollutants that are generated during the process include $\mathrm{CO}_{2}, \mathrm{SO}_{2}, \mathrm{HF}$, and particulate matter (dust). According to the literature, every tonne of magnesium that produced via the Pidgeon process produces $24-34 \mathrm{~kg}$ of $\mathrm{HF}$ and $85-110 \mathrm{~kg}$ of particulate matter [1]. A scaled-down pilot Pidgeon process was carried out to reduce magnesium with double reduction retorts that each held $10 \mathrm{~kg}$ of pellets. The migration of fluorine in the experiment was studied, and the thermodynamic software FACTSAGE was used to verify the results [2]. After excluding the experimental error and taking the average value, it was found that more than $90 \%$ of the fluorine that was in the raw materials ultimately entered the magnesium slag $[2,3]$.

China is the world's largest magnesium producer. In 2007, China's primary magnesium output accounted for more than $80 \%$ of the world's total output [4]. A comparison of China's magnesium output to the world's magnesium output from 2001 to 2007 is shown in Fig. 3.5 [4].

At present, magnesium metallurgy via the Pidgeon process accounts for nearly 95\% of the total magnesium production in China [5]. Except for a small amount of magnesium slag that is recycled, most of magnesium slag is discarded as waste. With the accumulation or landfill of a large amount of magnesium slag, hazardous substances that are in magnesium slag dissolve out in the rain. The flowing of hazardous substances into rivers and lakes has a serious impact on crops and the surrounding environment, and this seriously endangers human health and crop growth. The "European Landfill Directive 1999/31/EC" sets fixed emission limits for the emission concentration of various pollutants. If the concentration of a pollutant in waste exceeds the limit, direct landfill of the waste is prohibited, and the waste must be pretreated. However, if the concentration of the pollutant that is discharged in the waste is lower than the limit, it is considered that the waste will not cause great harm to the environment and that it can be directly landfilled without pretreatment. The emission limits of some important elements in this standard are shown in Table 3.4. 


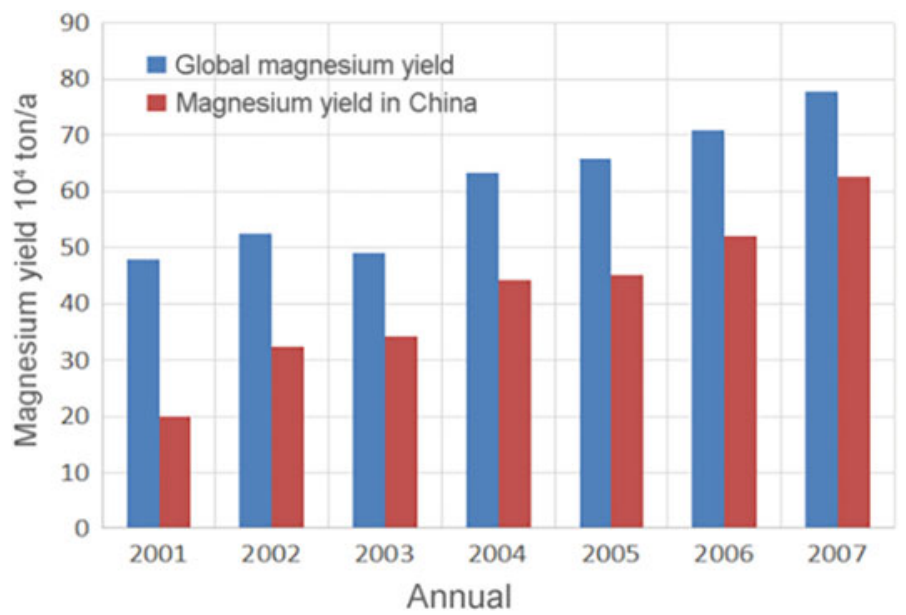

Fig. 3.5 Magnesium output $\left(10^{4}\right.$ tonne $)$ of China and worldwide

Table 3.4 Emission limits of some important elements in the "European Union Waste Landfill Guidelines"

\begin{tabular}{l|l|l|l|l|l|l|l|l}
\hline Elements & $\mathrm{Cr}$ & $\mathrm{Mo}$ & $\mathrm{Cu}$ & $\mathrm{Cd}$ & $\mathrm{F}$ & $\mathrm{Pb}$ & $\mathrm{Zn}$ & $\mathrm{Ni}$ \\
\hline Limit $(\mathrm{mg} / \mathrm{kg})$ & 0.5 & 0.5 & 2.0 & 0.04 & 10.0 & 0.5 & 4.0 & 0.4 \\
\hline
\end{tabular}

Professor Han Fenglan of North Minzu University conducted leaching experiments on magnesium slag samples using to the standard procedure in EU EN 124572 "Characterization of Waste-Leaching; Compliance test for leaching of granular waste materials and sludges", and the results are shown in Table 3.5 [6].

As seen from the test results shown in Table 3.5, the fluorine in magnesium slag that is generated via the Pidgeon process seriously exceeds the standard limit. Thus, the slag cannot be landfilled directly because it will cause serious consequences.

Table 3.5 Leaching experiment results of magnesium slag generated by Huiye Magnesium Enterprise (measured according to EU standard)

\begin{tabular}{|c|c|c|c|c|c|c|c|c|c|}
\hline Element & $\mathrm{Ca}$ & $\mathrm{Mg}$ & $\mathrm{Na}$ & K & $\mathrm{F}$ & $S$ & $\mathrm{Al}$ & $\mathrm{pH}$ & $\begin{array}{l}\text { Conductivity } \\
(\mu \mathrm{s} / \mathrm{cm})\end{array}$ \\
\hline $\begin{array}{l}\text { Test } \\
\text { value } \\
(\mathrm{mg} / \mathrm{kg})\end{array}$ & 1970 & 0.9 & 18.7 & 16.8 & 72.9 & 30.4 & 84.3 & \multirow[t]{3}{*}{13.4} & \multirow[t]{3}{*}{1764} \\
\hline Element & $\mathrm{Cr}$ & Mo & $\mathrm{Cu}$ & $\mathrm{Cd}$ & $\mathrm{Ni}$ & $\mathrm{Pb}$ & $\mathrm{Zn}$ & & \\
\hline $\begin{array}{l}\text { Test } \\
\text { value } \\
(\mathrm{mg} / \mathrm{kg})\end{array}$ & 0.042 & 0.207 & 0.017 & 0.0005 & 0.005 & 0.002 & 0.047 & & \\
\hline
\end{tabular}


Table 3.6 Leaching results of magnesium slag sample based on China's national standard

\begin{tabular}{l|l|l}
\hline Initial leaching solution & Distilled water with $\mathrm{pH}=6.9$ & $\begin{array}{l}\text { Distilled water with } \mathrm{pH}=3.2 \\
\text { (pH adjusted using sulfuric } \\
\text { acid and nitric acid) }\end{array}$ \\
\hline $\begin{array}{l}\text { Fluorine content in leaching } \\
\text { solution }(\mathrm{mg} / \mathrm{kg})\end{array}$ & 139.0 & 139.5 \\
\hline
\end{tabular}

Similarly, with reference to HJ/T299-2007 "Solid waste-Extraction procedure for Leaching Toxicity-Sulfuric acid and nitric acid method" issued by the Ministry of Environmental Protection of China, the magnesium slag was leached, and the results are shown in Table 3.6.

The maximum concentration of fluorine emission as defined in the national standard GB5749-2006 for drinking water safety is $10 \mathrm{mg} / \mathrm{kg}$. The detected fluorine content in the leaching experiment of magnesium slag was as high as 14 times of the limit. On the basis of the above experimental results, the following conclusions can be drawn: the fluorine content in magnesium slag exceeds the maximum limit several times according to the EU standard, or more than 10 times greater than the maximum limit, according to the China's national standard. Therefore, direct stacking and landfilling of untreated magnesium slag can easily cause fluorine leaching from the magnesium slag, and this poses a great threat to drinking water.

\subsubsection{Dust Pollution}

As seen from Figs. 3.1 and 3.2, after the reaction is complete and the slag is discharged at high temperature, the magnesium slag that is naturally cooled and weathered contains a large number of tiny particles that have a size range of $1-10 \mu \mathrm{m}$; this causes dust to spread in the storage location. The spread of dust pollutes the environment and makes collection and transportation inconvenient. The harms that dust has on the human body include: (1) Hard and sharp-shaped dust can cause mechanical damage to the human respiratory mucosa. (2) Long-term inhalation of a certain amount of dust can result in dust gradually depositing in the lungs, causing the lungs to produce progressive and diffuse fibrous tissues; the resultant respiratory disease is called pneumoconiosis. (3) Inhalation of a certain amount of silica dust hardens lung tissue and causes silicosis. In addition, toxic dust that mainly containing sulfur dioxide flue gas has become the main factor that affects the air environment in China. China's national standard classifies the dust that is generated at an industrial production site into total dust and respirable dust. Total dust is defined as "dust that can enter the entire respiratory tract (nasopharynx and throat, thoracic bronchus, bronchioles, and alveoli)", and respirable dust refers to dust that is deposited in the alveolar area. The British Medical Research Council (BMRC) proposed in 1952 that the deposition efficiency of particles with an aerodynamic diameter of $5 \mu \mathrm{m}$ is $50 \%$, and the deposition efficiency of dust with an aerodynamic diameter greater than $7.07 \mu \mathrm{m}$ 
is 0. The American Conference of Governmental Industrial Hygienists (ACGIH) stipulates that the deposition ratio of dust particles with an aerodynamic diameter of $3.5 \mu \mathrm{m}$ is $50 \%$, and the deposition ratio of dust particles with an aerodynamic diameter greater than $10 \mu \mathrm{m}$ is 0 . BMRC regulation of respirable dust is used in China. Dust particles that are larger than $10 \mu \mathrm{m}$ usually fall under the action of their own weight, whereas dust particles that are smaller than $10 \mu \mathrm{m}$ easily form flying dust, smoke, and smog. These particles remain in the air for a long time and are easily inhaled by the human body, causing severe harm. Two of the main components in magnesium slag are $\mathrm{SiO}_{2}$ and $\mathrm{CaO}$. Free silica dust has been listed as a human carcinogen by the International Cancer Research Center. Dust that contains these substances may cause tumors in the respiratory system or other tissues.

\subsection{Current Status of Comprehensive Utilization of Magnesium Slag}

Statistics show that the output of China's magnesium industry was 873,900 tons in 2014 and 863,900 tons in 2018. The outputs of magnesium in China from 2014 to the first half of 2019 are shown in Fig. 3.6 [7].

The Pidgeon process produces 7-8 tonnes of reduced slag for every onetonne of magnesium that is produced. The rapid development of China's magnesium industry is accompanied by the emission of a large amount of magnesium slag. A large

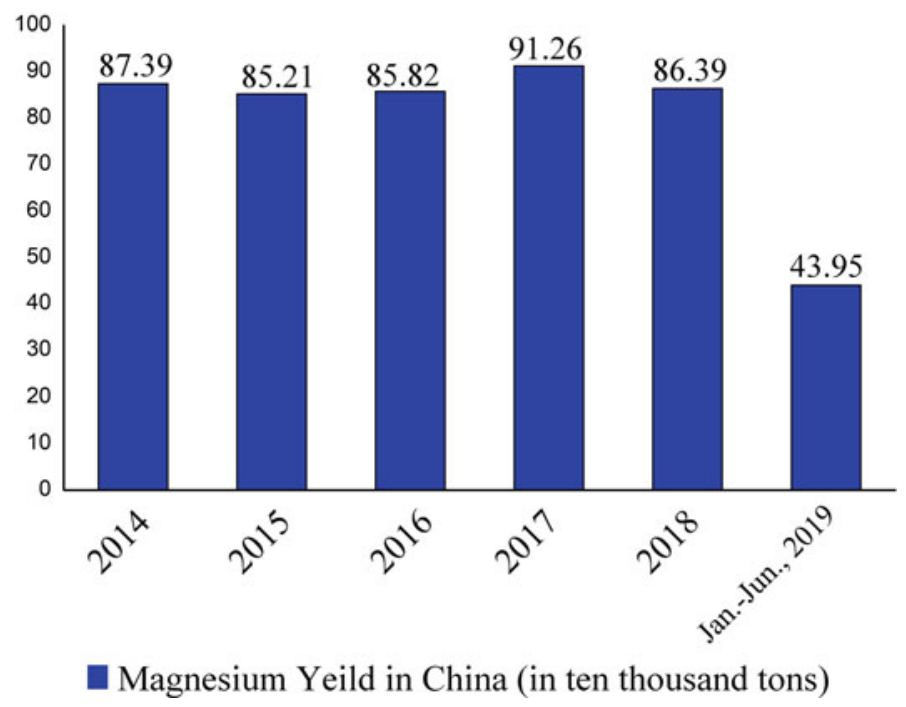

Fig. 3.6 Outputs of China's magnesium industry from 2014 to the first half of 2019. Data source China nonferrous metals industry association 
amount of magnesium slag is still piled up or landfilled. This occupies, a lot of precious land, and also has a great impact on the surrounding environment; it can seriously endanger human health and the growth of animals and plants. Therefore, how to fully utilize magnesium slag has become a limiting factor in the sustainable development of the magnesium industry in China. At present, research hotspots regarding the recycling and reuse of magnesium slag in China mainly focus on the following aspects: using magnesium slag as a desulfurizer, replacing lime as a slagmaking agent in steelmaking, preparing cement clinker and using it as an additive in mixtures with other materials to activate cement, preparing building materials, preparing fertilizer and preparing geopolymers.

\subsubsection{Magnesium Slag as a Desulfurizer}

With the rapid development of economic construction, China's coal-dominated energy consumption increases productivity and creates huge material wealth, but it has also brought a large amount of sulfur dioxide emissions and caused a tremendous strain on the environment. At present, the most frequently used desulfurizers in industry are limestone and dolomite. The principle is to use alkaline oxide or carbonate to react with sulfur dioxide and then to generate sulfate or sulfite to achieve the purpose of sulfur fixation. The amount of $\mathrm{CaO}$ in magnesium slag is as high as 40-50\%, which is a favorable condition for using magnesium slag as a desulfurizer. The research team of Fan Baoguo of Taiyuan University of Technology carried out a large number of experimental studies on the desulfurization performance of magnesium slag[8-15]. Zhao Jianli et al. [16] and Xiao Yongqiang et al. [17] also reported relevant studies. Xu Xiangbin et al. used magnesium slag as a sulfur fixing agent for fire coal and an industrialization test was carried out for the desulfurization of molten iron that is produced by iron and steel plants. When magnesium slag was used as desulfurization agent in the steel industry, a desulfurization efficiency over $80 \%$ was achieved $[18,19]$.

\subsubsection{Preparation of Cement and Construction Materials via Magnesium Slag}

The team led by Cui Zizhi of Ningxia University carried out a series of studies on the preparation of magnesium slag concrete via the mixing of magnesium slag and other solid wastes and studied the strength, carbonization characteristics and shrinkage mechanism of the prepared magnesium slag concrete [20-22]. Chen Guanjun [23], Ji Ying et al. [24] of Xi' an University of Architecture and Technology studied the properties of controllable expansive cementitious materials and cement cementitious materials that were prepared using magnesium slag. Ji Guangxiang of 
Chongqing University studied the preparation and performance of alkali-magnesium slag concrete without the use of an autoclave and aeration [25]; Peng Xiaoqin et al. studied the preparation of magnesium slag bricks [26]. Luo Feng and Xiao Liguang of Jilin Institute of Architecture and Engineering studied the preparation mechanism of cementitious materials that contain magnesium slag and the preparation of magnesium slag wall materials [27-30]. Fang Renyu et al. tested the use of magnesium slag instead of limestone to calcinate cement clinker. The results showed that at a calcination temperature of $1450{ }^{\circ} \mathrm{C}$ and with a calcination time of $30 \mathrm{~min}$, the properties of the clinker met the standard when $15 \%$ of the limestone content was replaced by magnesium slag. Mechanism analysis indicated that this result is related to the facts that there are higher contents of $\mathrm{CaO}$ and $\mathrm{SiO}_{2}$ in magnesium slag and that the main mineral component is $\mathrm{C}_{2} \mathrm{~S}$ [31]. Professor Han Fenglan of North Minzu University used magnesium slag and manganese electrolytic slag to prepare sulphate aluminum cement clinker. Manganese electrolytic slag was found to contained dihydrate gypsum, and magnesium slag contained $\mathrm{C}_{2} \mathrm{~S}$. Moreover, the main chemical components of magnesium slag are $\mathrm{Fe}_{2} \mathrm{O}_{3}, \mathrm{SiO}_{2}, \mathrm{Al}_{2} \mathrm{O}_{3}$, and $\mathrm{CaO}$, and this is consistent with the main chemical components in sulfate cement clinker. Calculations determined that the content of manganese electrolytic slag and magnesium slag in the raw material can each be as high as $21 \%$. The best sintering temperature for the raw materials is $1260{ }^{\circ} \mathrm{C}$, and the holding time is $30 \mathrm{~min}$. The mineral phase of the sample that was sintered at these conditions mainly contains $\mathrm{C}_{2} \mathrm{~S}$ and $\mathrm{C}_{4} \mathrm{~A}_{3} \mathrm{~S}$. The addition a certain amount of gypsum to the prepared cement clinker enhances the mechanical properties of the cement clinker. When the added amount was $15 \%$, the total heat of hydration that was released reached a maximum, and the mechanical properties were optimal. The 28-day flexural strength was $5.1 \mathrm{MPa}$, and the 28-day compressive strength was 31.2 MPa [6, 32]. Tian Lei used ceramic filter balls made of magnesium slag or red mud as an adsorption material; $\mathrm{TiO}_{2}$ was loaded on the two types of ceramic filter balls to modify the surface, and then the mechanism when the $\mathrm{TiO}_{2}$-loaded ceramic filter ball was used to remove arsenic in water was studied [33]. Zhou Shaopeng used Shanxi Yangquan bauxite, pyrolusite powder, and magnesium slag as raw materials to prepare cylindrical ceramsite proppant materials and studied the pelletizing and sintering processes of ceramsite proppant and its relevant properties [34].

\subsubsection{Use Magnesium Slag to Replace Lime as a Slagging Agent in Steelmaking}

The international scientific and technological cooperation project "Collaborative Research on Comprehensive Treatment and Recycling Technology for Mg slag" was undertaken by the North Minzu University, the Iron and Steel Research Institute, and enterprises in Ningxia province. Rare earth oxides or borate were used 
as a mineralizer in magnesium reduction to replace calcium fluoride, and fluorinefree magnesium slag was obtained. The team of co-operation used the fluorine-free magnesium slag to partially replace limestone as a slagging agent in steelmaking. $\mathrm{Na}$ Xianzhao et al. of the Iron and Steel Research Institute first conducted a small laboratory test to confirm that there were no adverse effects on the quality of the simulated steelmaking product, and then, they carried out two batches of multi-furnace production tests at the Ningxia steelmaking plant. The maximum content of fluorine-free magnesium slag that is used to replace lime can be as high as $30 \%$, provided that there are no adverse effects on the quality of the steel product [6].

\subsubsection{Preparation of Ca-Mg Composite Fertilizer Using Magnesium Slag}

Li Yongling of Shanxi University [35] studied the preparation of magnesium slagbased slow-release Si-Ca-K composite fertilizer. The study revealed that there are few soluble components in magnesium slag. The contents of heavy metals in magnesium slag meet the national standard for organic-inorganic composite fertilizer, and the specific activity of radionuclides, the internal exposure index, and the external exposure index all meet the radioactivity requirements of the national standard for Class A decoration materials. The effective leaching amount of heavy metals in magnesium slag is far below the minimum limit of toxicity identification. Also, magnesium slag contains elements that are necessary or beneficial for soil and crops, indicating that it has a high environmental safety and poses a low pollution risk. Magnesium slag can be modified with potassium carbonate to prepare a new type of slow-release Si-Ca-K composite fertilizer. A corn potting experiment used the fertilizer and verified that it improved the agronomic characteristics of corn and increased the amount of dry matter and yield of corn. Additionally, acidic soil is more conducive to the effective release of $\mathrm{Si}$ and $\mathrm{K}$ in composite fertilizer than alkaline soil. Ge Tian [36] studied the fertility characteristics and agricultural environmental risk assessment of $\mathrm{Si}-\mathrm{K}$ fertilizer that is made from magnesium slag. Liang Yiran and Mao Jia [37, 38] of Taiyuan University of Technology also studied the feasibility and technological process of preparing Si-Ca-K composite fertilizer from magnesium slag. Wang Yan of Zhengzhou University [39] studied the comprehensive utilization of magnesium slag to prepare Si-Ca-Mg fertilizer. The results indicated that the amounts of harmful trace elements in magnesium slag were not high and were all lower than the requirements in "GB8173-87" for Pb and Cd. The prepared Si-Ca-Mg fertilizer contained $20.34 \%$ of effective silicon; $85 \%$ of the fertilizer particles can pass through a 60 mesh standard sieve, and the moisture content was $0.89 \%$, which meets the national standard for silicon fertilizer. 


\subsection{Advantages and Technical Difficulties in Recycling Utilization of Magnesium Slag}

For the magnesium slag produced by silicothermal reduction via the Pidgeon process, the main chemical composition is $40-50 \%$ calcium oxide and $20-30 \%$ silicon dioxide, in addition to unreacted magnesium oxide and iron oxide. Heavy metals are rarely detected. Therefore, the recycling process can more easily be conducted without the need to detoxify heavy metals, and this is a major advantage of the comprehensive use of magnesium slag. However, there are several technical problems to solve: (1) The particles of magnesium slag are small, easily cause dust to rise, are light in specific gravity, and are inconvenient to transport. Thus, there is an effective radius for the economic feasibility for the bulk use of magnesium slag. Meanwhile, magnesium smelters are often established in remote areas, where raw material mines are located. They are far away from economically developed and industry-intense areas, and this makes recycling magnesium slag difficult. Although it is technically possible to change the proportion and appearance of magnesium slag through densification and modification, the economic feasibility must first be considered for the bulk use of magnesium slag, and the increase in processing costs often outweighs the gains. (2) In addition to landfilling, the current magnesium slag use in China mostly involves replacing limestone to prepare cement clinker. However, as $3-8 \% \mathrm{MgO}$ remains in the magnesium slag, there is a later expansion in the longterm use of cement products. As a hidden danger, the later expansion causes product failure, and thus, it requires serious study and treatment. (3) Calcium fluoride in untreated magnesium slag reacts easily when is stored in the open air and is landfilled. Furthermore, it is converted at high temperature during treatment $[40,41]$, and there is even a risk of the spread of fluorine pollution. Therefore, it needs to be given more concentration during further recycling process.

\section{References}

1. Gao F, Nie Z, Wang Z et al (2008) Environmental assessment of energy usage strategies for magnesium production using the Pidgeon process. J Beijing Univ Technol 34(6):646-651

2. Wu L, Han F, Yang Q et al (2012) Fluoride emissions from Pidgeon process for magnesium production. In: Paper presented at the 27 th international conference on solid waste technology and management, Philadelphia, 11-14 March 2012

3. Han F, Yang Q et al (2012) Environmental performance of fluorite used to catalyze $\mathrm{MgO}$ reduction in Pidgeon process. Adv Mater Res 577:31-38

4. Zhang Y (2013) Researching on the dynamics and parameters optimization of smelting magnesium by silicon-thermo-reduction. Dissertation, Jilin University

5. Ramakrishnan S, Koltun P (2004) Global warming impact of the magnesium produceng the Pidgeon process. Resour Conserv Recycl 42:49-64

6. Han F, Wu L (2017) Recycling utilization of industrial solid waste. Science Press, Beijing

7. China Science Research (2019) Development status and investment strategy report of Chinese magnesium industry (2018-2023) 
8. Fan B, Duan L et al (2015) Fractal characteristics on Pore structure of Magnesium slag as desulfurizer. J Eng Thermophys 36:678-682

9. Fan B, Yang J et al (2013) Study of the denaturing of the agent for desulfurizing magnesium slag through hydration by using additives. J Eng Therm Energ Power 28:415-419+440-441

10. Han F, Jia L et al (2019) Effect of crystal structure on the desulfurization reactivity of magnesium slag. Chem Ind Eng Prog 38(07):3319-3325

11. Chen J, Han Fet al (2019) Study on dissolution characteristics and desulfurization performance of quenching hydration magnesium slag. Boiler Technol 50(02):1-5+34

12. Ji K, Hou Y et al (2016) Experiment on desulfurization performance of magnesium slag modified by quenching hydration. Chin J Environ Eng 10(12):7235-7240

13. Duan L (2015) Study on fractal characteristics of hydration products from quenching magnesium slag. Dissertation, Taiyuan University of Technology

14. Feng L (2018) Study on wet desulfurization of various forms magnesium slag. Dissertation, Taiyuan University of Technology

15. Wang X (2010) Experimental investigation on reaction characteristics for magnesium residues as sorbent. Dissertation, Taiyuan University of Technology

16. Zhao J (2011) A study on dissolution mechanism and desulfurization performances of Alkaline industrial wastes. Dissertation, Shandong University

17. Xiao Y, Gao Y (2018) Preparation and performance test of new environment-friendly desulfurizer containing magnesium slag. Environ Eng 36(11):133-136

18. Xu X (2011) Investigation of magnesium slag via Pidgeon Process as Sulfur fixation agent for coal burning. Dissertation, Jiangxi University of Technology

19. Xu X, Chen Y et al (2017) Industrial test of desulfurization of hot metal by magnesium slag. Light Metals 1:42-44

20. Cui Z, Li S et al (2016) Drying shrinkage characteristics of magnesium slag composite admixture concrete. J Sichuan Univ (Engineering Science Edition) 48(02):207-212

21. Li Z (2016) Experiment study on carbonization properties of magnesium slag concrete. Dissertation, Ningxia University

22. Cui Z, Zhou K et al (2013) Study on the strength characteristics of magnesium slag fine aggregate concrete. Concrete 06:67-69

23. Chen G (2015) Study on controllable expansion of cementitious materials for preparing magnesium slag. Dissertation, Xi' an University of Architecture and Technology

24. Ji Y, Li Y et al (2017) Properties of quenching magnesium slag cement cementitious materials. J Xi' an Univ Arch Tech 49(02):277-283

25. Peng X, Wang $\mathrm{K}$ et al (2013) Hydraulic potential stimulation and bricks preparation of magnesium slag. J Chongqing Univ 36(03):48-52+58

26. Ji G (2016) Research on preparation and performance of non-autoclaved curing aerated concrete prepared from alkali activated magnesium slag. Dissertation, Chongqing University

27. Luo F (2010) Study and application of minor clinker magnesium slag cementitious material. Dissertation, Jilin architectural and civil engineering institute

28. Xiao L, Luo F et al (2009) The analysis on mechanism of using magnesium slag to prepare the cementitious material. J Jilin Inst Arch Civil Eng 26(05):1-5

29. Xiao L, Luo F et al (2011) Study of new magnesium slag energy-saving insulation wall material. Xxxxxx 38(07):21-23

30. Xiao L, Wang S et al (2008) Status research and applications of magnesium slag. J Jilin Inst Arch Civil Eng 01:1-7

31. Fang R, Che S et al (2014) Study on properties of cement clinker calcined with magnesium slag as one of raw materials. Cement 11:26-28

32. Zhao S, Han F et al (2017) Preparation of composite slag sulphoaluminate cement clinker from electrolytic manganese-magnesium. Bull Chin Ceram Soc 36(05):1766-1772+1776

33. Tian L (2010) Study on magnesium slag and red mud utilization of ceramic filter ball to remove As from wastewater. Dissertation, Wuhan University of Technology

34. Zhou S (2014). Effect of magnesium slag doping on the property of ceramsite proppant material. Dissertation, Taiyuan University of Science and Technology 
35. Li Y (2016) Preparation and properties of slow releasing Silicon-potash fertilizer by using magnesium slag. Dissertation, Shanxi University

36. Ge T (2016) Fertility properties of magnesium slag-based Si-K fertilizer and agricultural environmental risk assessment. Dissertation, Shanxi University

37. Liang Y (2015) Feasibility of using magnesium slag to produce Si-Ca-Mg compound fertilizer and research of improving the content of available silicon. Dissertation, Taiyuan University of Technology

38. Mao J (2016) Using magnesium reducing slag to produce $\mathrm{Ca}-\mathrm{Mg}$-Si compound fertilizer and its applied basic research. Dissertation, Taiyuan University of Technology

39. Wang Y (2012) Comprehensive utilization of magnesium slag study and analysis on preparation of silicon, calcium and magnesium fertilizers. Dissertation, Zhengzhou University

40. Han F et al (2012) Fluoride evaporation during thermal treatment of waste slag from $\mathrm{Mg}$ production using Pidgeon process. Adv Mater Res 581-582:1044-1049

41. Wu L et al (2013) Fluorine vaporization and Leaching from Mg Slag treated at different conditions. Adv Mater Res 753-755:88-94

Open Access This chapter is licensed under the terms of the Creative Commons AttributionNonCommercial-NoDerivatives 4.0 International License (http://creativecommons.org/licenses/bync-nd/4.0/), which permits any noncommercial use, sharing, distribution and reproduction in any medium or format, as long as you give appropriate credit to the original author(s) and the source, provide a link to the Creative Commons license and indicate if you modified the licensed material. You do not have permission under this license to share adapted material derived from this chapter or parts of it.

The images or other third party material in this chapter are included in the chapter's Creative Commons license, unless indicated otherwise in a credit line to the material. If material is not included in the chapter's Creative Commons license and your intended use is not permitted by statutory regulation or exceeds the permitted use, you will need to obtain permission directly from the copyright holder.

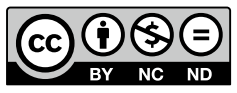

